\title{
ETHNIC POLICY IN TRANSBAIKALIA AT THE SECOND HALF OF THE 19TH - EARLY 20TH CENTURIES: REGIONAL NUANCES
}

\author{
Lilia V. Kalmina \\ The Institute for Mongolian, Buddhist and Tibetan Studies, Siberian Branch, Russian Academy \\ of Sciences. Ulan-Ude, Russia. Email: kalminal[at]gmail.com
}

\begin{abstract}
The article is devoted to the regional peculiarities of ethnic policy having been analyzed on the example of Transbaikal region of Russian Empire. During the period under investigation it was a kind of national outlying district which lagged behind other Siberian territories in social-economic and cultural development. At the same time it was closely connected with foreign policy ambitions of the Empire which considered it as starting point for strengthening economic and political influence in Inner Asia. Geopolitical potential of the region and its unpreparedness to play the intended role defined ethnic policy mode. Frontier position of the region demanded the necessity of administrative system unification in order to provide unity of its indigenous population (Buryats) with Russian people. Nevertheless, insufficient flexibility in this issue caused protest movement growth and was the reason of region vulnerability against foreign threat. Transbaikalia economic reinforcing acceleration at last defined comparatively mild variant of relations arrangement with none-indigenous ethnic groups in spite of the exiled status and established opinion of their unreliability. Regional administration regarded them as promising colonization element, having high educational potential, as well as business experience in frames of free competition, local population having no such. This policy allowed former exiles to fit regional society organically and display their abilities to the full extent.
\end{abstract}

The results obtained may be used while researching regions' independence degree in decision making in ethnic issue and possibility of official course correction due to the status of the region and thus peculiarities of its development.

\section{Keywords}

Ethnic Policy; Transbaikalia; Regional Administration; Frontier Territory; Indigenous Dwellers Policy; Non - Indigenous Ethnic Groups; Poles; Jews; Chinese; Legal Status 


\section{ЭТНИЧЕСКАЯ ПОЛИТИКА В ЗАБАЙКАЛЬЕ ВО ВТОРОЙ ПОЛОВИНЕ ХІХ - НАЧАЛЕ ХХ ВВ.: РЕГИОНАЛЬНЫЕ НЮАНСЫ}

\section{Кальмина Лилия Владимировна}

Институт монголоведения, буддологии и тибетологии Сибирского отделения Российской академии наук. Улан-Удэ, Россия. Email: kalminal[at]gmail.com

\section{Аннотация}

Статья посвящена региональным особенностям этнической политики, которые автор анализирует на примере Забайкальской области Российской империи. В исследуемый период регион был типичной «национальной окраиной», отстававшей в своем социально-экономическом и культурном развитии от других сибирских территорий. В то же время с ним связывались внешнеполитические амбиции империи, которая рассматривала его в качестве стартовой площадки для укрепления во внутриазиатском пространстве своего экономического и политического влияния. Геополитический потенциал региона и его неготовность играть предназначенную ему роль определили его собственную линию этнической политики. Приграничное положение области диктовало необходимость унификации управленческой системы для обеспечения единства ее коренного населения - бурят - с русским народом. Однако недостаточная гибкость в этом вопросе вызвала рост протестного движения и усилила уязвимость региона перед внешней опасностью. Задачи ускорения экономического укрепления Забайкалья в конечном итоге определили сравнительно мягкий вариант выстраивания отношений с некоренными этническими группами, несмотря на статус ссыльных и устоявшееся мнение об их неблагонадежности. Региональная администрация рассматривала их в качестве перспективного колонизационного элемента, имеющего высокий образовательный потенциал и опыт предпринимательства в условиях свободной конкуренции, которого у местного населения не было. Такая политика позволила бывшим ссыльным органично вписаться в местный социум и в полной мере проявить имеющиеся навыки.

Полученные результаты могут быть применены при исследовании степени самостоятельности регионов в принятии управленческих решений в этническом вопросе и возможности корректировки официального курса в зависимости от статуса региона и определенных им особенностей его развития.

\section{Ключевые слова}

этническая политика; Забайкальская область; региональная администрация; окраинная территория; инородческая политика; некоренные этнические группы; поляки; евреи; китайцы; правовой статус

Это произведение доступно по лицензии Creative Commons «Attribution» («Атрибуция») 4.0 Всемирная 


\section{ВВЕДЕНИЕ}

Прежде чем приступить к основному повествованию, считаем нужным уточнить два момента. Во-первых, при анализе политики самодержавия по отношению к народам Забайкалья мы сознательно использовали именно категорию «этническая», а не «национальная», будучи вполне согласны с определением исследователей, трактующих «национальное» не как обозначение административной формы внутреннего этнотерриториального самоопределения («национальная республика»), а как единое национальное государство с единой многоэтничной нацией (Тишков, 2013, сс. 5, 7). Следовательно, под национальной политикой понимается система мер по обеспечению безопасности государства. Государственную же политику по отношению к населяющим ее народам считаем этнической. Во-вторых, хотя региональная этническая стратегия в основном следовала в русле имперского законодательства, отклонения от него в сторону ужесточения или смягчения были неизбежны в силу разнородности регионов империи, отличающихся по времени вхождения в ее состав, географическому положению, уровню социально-экономического развития, этнической структуре и т.д. Определенное влияние на региональную этническую политику оказывал и субъективный фактор - собственные представления регионального администратора о том, как надо регламентировать жизнь того или иного народа, живущего на подведомственной ему территории. Роль субъективного фактора в сибирской этнической политике мы ранее рассматривали на примере отношения губернаторского и генерал-губернаторского звена власти к еврейской общности (Кальмина, 2020). Ни в коем случае не абсолютизируя региональную «особость», ставим целью определить степень ее значимости в проведении этнической политики на окраинной территории.

Для иллюстрации региональных особенностей мы избрали Забайкальскую область Российской империи. На наш взгляд, это очень удачная историческая площадка для проведения такого рода исследования. Во-первых, в силу ее геополитической роли торгово-промышленного плацдарма для последующего экономического доминирования России во Внутренней Азии. Само создание области в 1851 г. в качестве административно-территориального образования было в значительной мере подготовлено для предупреждения потенциально опасных тенденций складывавшегося на Востоке положения (Мерцалов, 2008, с. 29). Во-вторых, область была местом постоянного проживания одного из крупнейших коренных сибирских этносов - 
бурят. Это требовало тщательно продуманной политики: этническая турбулентность в приграничном регионе не только не позволила бы ему выполнить роль проводника российского влияния во Внутренней Азии, но и создала бы угрозу безопасности империи на ее восточных рубежах. Наконец, Забайкалье было местом массовой ссылки, обусловившей формирование нескольких этнических общностей, которые никогда бы здесь не появились, не стань их представители объектами принудительной миграции, и которые предстояло интегрировать в разнородное забайкальское общество.

\section{БУРЯТЫ: ЖЕСТКИЕ ПОСЛЕДСТВИЯ «МЯГКОЙ СИЛЫ»}

Стержнем этнической политики в регионе стало определение отношения к коренному населению. Согласно Первой Всеобщей переписи 1897 г., буряты составляли 178 тыс. чел. из 672 тыс., т.е. больше четверти населения Забайкальской области. Трансформация «инородческой» политики в регионе прошла длительный путь, продиктованный процессом инкорпорации окраинной территории в единое общеимперское политическое и хозяйственно-экономическое пространство, что, в свою очередь, составляло одну из приоритетных задач российского правительства в XIX в. (Дамешек, 2013, с. 218). Государство ценило забайкальских инородцев как исправных плательщиков ясака и практиковало по отношению к ним политику постепенного встраивания в сложившуюся систему общественных отношений, откровенно заигрывая с местной элитой. Административная инфраструктура учитывала определенные традиции этноса вплоть до названия административно-территориальных единиц и традиционного «национального» законодательства. На низшем уровне допускалось «инородческое» самоуправление. А при разборе «маловажных» дел коренное население с разрешения центральной власти руководствовалось нормами обычного права (Дамешек, 2012, сс. 15, 16). Возможное смешение русского с коренными народами даже приветствовалось как своего рода элемент «мягкой силы». Предполагалось, что возможная ассимиляция будет проходить в направлении поглощения «отсталых» народов империи, которые постепенно войдут в круг более развитой русской культуры. Однако все пошло не «по плану». Во многих случаях вопреки ожиданиям чиновников и интеллектуальной элиты не столько инородцы подвергались обрусению, сколько русские «обынородчивались», скатываясь по лестнице выстроенной русскими учеными иерархии культур народов империи, на верхней ступени которой находились оседлые земледельцы - пред- 
почтительно православные и предпочтительно славяне. На глазах рушился миф о культурном превосходстве русского крестьянина над восточными народами империи (Сандерланд, 2005, сс. 199, 202, 203, 204).

В конце XIX - начале XX вв. вектор российской «инородческой» политики кардинальным образом меняется. Империя начинает отходить от регионализма в управления окраинами. На смену ему приходит понимание необходимости унификации управленческой системы, без чего была невозможна полная интеграция окраинных территорий в империю. Со времени принятия «Устава об управлении инородцев» (1822 г.), в основу которого было положено родовое начало, прошло уже много времени. В экономической и социальной жизни инородцев произошли серьезные изменения, связанные с переходом к оседлому образу жизни и распадом родового строя. Инородцам Забайкальской области предполагалось дать устройство, «сообразованное в главных своих началах с организацией прочего сельского населения империи» (Жалсанова, 2013, сс. 168, 169).

Процесс унификации систем управления во всех окраинах объективно соответствовал логике имперской политики их окончательной интеграции. Однако есть все основания утверждать, что в исследуемом регионе инициатива приведения управления к общему знаменателю исходила с мест. В Западной Сибири администрация с трудом привыкала к идее ввиду «положительно невозможного» причисления аборигенов к русским волостям из-за разницы в вероисповедании, языке, обычаях и из-за «обоюдного нерасположения друг к другу русских и инородцев». Но в Восточной Сибири ее проводниками стали чиновники генерал-губернаторского и губернаторского уровня. Из их уст мнение о том, что сохранение особых положений для управления аборигенами «не только бесполезно, но даже вредно» и следует подчинить их «общим действующим в России законам, сравняв права и обязанности их с крестьянами», стало звучать все настойчивее (Дамешек, 2018, с. 232). Забайкальские областные начальники в этом вопросе были даже более последовательны и бескомпромиссны, чем генерал-губернаторское звено. Военный губернатор Забайкальской области И.К. Педашенко еще в 1878 г. во всеподданнейшем отчете поставил вопрос о распространении форм «русского» административно-территориального управления на «инородцев». Военный губернатор П. И. Хорошхин, едва вступив в должность, представил проект лишения бурят самоуправления и превращения их в казаков. А военный губернатор Е.О. Мациевский обосновывал необходимость 
упразднения инородческих органов управления - Степных дум тем, что они разъединяют население (Кальмина \& Малыгина, 2016, сс. 129, 130). На наш взгляд, настойчивость забайкальских «начальников края» диктовалась приграничным положением вверенного им региона, что изначально предполагало постоянно существующую опасность военных конфликтов. А коренное население, «обособленное» от русских сибиряков своими обычаями, системой управления, языком и религией, считалось не вполне благонадежным и в качестве радетелей за русское дело не рассматривалось.

Надо заметить, что региональные инициативы в этническом вопросе, впоследствии получавшие силу закона, были не таким уж редким явлением. Чаще всего законотворческие новшества как раз и черпались из губернаторских отчетов, а те, в свою очередь, заимствовались из отчетов окружных/ уездных начальников. Подобный порядок принятия закона мы показали на примере изменения принципа расселения ссыльных евреев среди сибирских старожилов взамен прежнего порядка сосредоточения их отдельными поселениями. Инициировавший идею генерал-губернатор Восточной Сибири Н. Н. Муравьев-Амурский заимствовал ее из рапортов окружных исправников (Кальмина, 2006, сс. 394-396).

В начале XX в. правительство провело волостную реформу, упразднив этническое самоуправление бурят. Однако последствия этих мер оказались для царских сановников совершенно неожиданными. Бывшая лояльная официальному Петербургу национальная окраина превратилась в «горячую точку»: за два века в составе Российской империи буряты впервые выступили против государственных законов. Отдельные стихийные протесты вылились в массовое общенациональное движение. Отказы бурят от исполнения функций «крестьянских начальников» и последующая замена их лицами русского происхождения придало противостоянию характер межэтнического конфликта. Сопротивление бурят ликвидации традиционных органов самоуправления, по сути, стало борьбой за сохранение себя как этноса, где родовая аристократия, защищавшая их интересы, фактически сыграла роль символа национального единства (Иванов, Кальмина \& Курас, 2012, сс. 176, 179). События убедительно проиллюстрировали тезис, что не среди наций рождаются «национальные движения», a, наоборот, на почве культурного и политического национализма оформляется идея нации (Тишков, 2005, с. 24).

Важной составляющей государственной политики по обрусению инородцев было распространение православия как механизма укреп- 
ления позиций главенствующей церкви, а, следовательно, и самодержавия на окраинах империи. «Мягкая сила» в процессе интеграции бурят в российское общество (принявшие православие на три года освобождались от уплаты ясака и даже от уголовных наказаний) сочеталась с фактами насильственного крещения. Последствия христианизации бурят были двоякими. С одной стороны, она, разрушая традиционный образ жизни этноса, породила защитную реакцию в виде массового ухода бурят в ламаизм, более адаптированный к сложившимся привычкам и верованиям. С другой, крещеные буряты, как и другие «инородцы», быстро приобщались к российской культуре, расширяли и активизировали хозяйственно-экономические и культурные связи с русским населением, становились мобильнее и социально активнее (Андреев, 2013, сс. 158-159). Введение для инородцев воинской повинности, освобождение от которой ранее было самой массовой льготой этнического характера (Дамешек, 2012, сс. 16-17), завершило серию реформ, направленных на уравнивание этой группы населения с остальными в отношении их обязанностей перед государством. Теперь, по мнению военных губернаторов Забайкалья, его население было «прочно спаяно во всех своих группах», что служило главным условием выполнения предназначенной ему роли оплота государства на Востоке.

Для завершения сюжета следует сказать о субъективном факторе в «инородческой» политике: предписания высших органов власти областные администраторы исполняли с разной степенью служебного рвения. Сторонником тактики «жесткой руки» был И. П. Надаров, бескомпромиссный в проведении реформ. Определив сроки замены органов родового управления волостными и сельскими правлениями, он ни при каких обстоятельствах не отступал от них, сурово карая несогласных. Более мягкой линии придерживался М. И. Эбелов, считавший, что притеснение бурят только осложнит ситуацию в приграничном регионе: недовольные курсом на унификацию предпочтут откочевать в Монголию, что уменьшит население области и тем ослабит ее экономику (Кальмина \& Малыгина, 2016, сс. 132-133, 136-137).

\section{НЕКОРЕННЫЕ ЭТНОСЫ: УХОД ОТ ОДНОМЕРНОСТИ}

В отличие от коренных народов Сибири, политика по отношению к которым была предметом постоянного интереса отечественных исследователей, изучение «приезжих» этнических групп долгое время выглядело, по меткому выражению Б. С. Шостаковича, «марги- 
нальным» направлением по отношению к «магистральной, основной истории» Сибири (2008, с. 183). Хотя такую характеристику известный полонист дал истории сибирских поляков, долгое пренебрежение их исторической ролью - удел практически всех этнических групп, оказавшихся в Сибири как продукт принудительной миграции. За последние два десятилетия этот пробел в значительной степени был ликвидирован: российские этнические меньшинства стали объектом пристального внимания российской и зарубежной историографии, а в Сибири история некоренных этносов сделала настоящий прорыв, обнаружив на региональном уровне многочисленные нюансы, отличающиеся от тенденций общероссийской этнической политики.

Своеобразную матрицу исследования истории народов России периода империи создал австрийский ученый А. Каппелер, привязавший государственную этническую политику к колонизационной, хотя автор избежал искушения полного подчинения своих изысканий господствовавшей «русоцентристской оптике». Уделяя первостепенное внимание взаимоотношениям между государством и нерусским населением периферийных регионов (Каппелер, 2000, с. 10), исследователь заложил традицию расширения узко национальных горизонтов для определения общих моментов и отличий в государственной этнической политике и адаптационных стратегиях разных народов с момента их вхождения в империю до полного социально-этнического и экономического обустройства. Эти традиция была развита отечественными исследователями, структурировавшими российскую этническую политику как своего рода «вопросник» («польский вопрос», «еврейский вопрос», «славянский вопрос») и твердо придерживавшимися данной концепции как наиболее удобной в изучении правового положения этносов в контексте имперской экспансионистской стратегии (Горизонтов, 2004; Миллер, 2012).

Этническая политика по отношению к некоренным этническим группам в Забайкалье определялась несколькими, часто противоположными, факторами. Во-первых, необходимостью ориентации на общеимперский курс, поскольку совершенно игнорировать его было нельзя даже при существенно отличающейся от европейской России ситуации. Во-вторых, географическими, демографическими и инфраструктурными особенностями регионов, их статусом в имперской модели власти. Этническая политика государства не была одномерной ни во времени, ни в пространстве, модифицируясь на разных этапах и разных территориях. Самодержавие отдавало себе отчет 
в невозможности полного подчинения разнородных окраин империи действию общеимперских юридических норм (Дамешек, 2005, сс. 155-156). В-третьих, тем фактом, что основной составляющей этнических общностей, оказавшихся в регионе в роли диаспоры, была ссылка. В данном контексте не всегда можно было провести четкую грань между отношением к ним как к меньшинствам и как к штрафной колонизации. Наконец, большую роль играли личные представления чиновников забайкальской администрации о способах решения «национального вопроса», поскольку компетенции высших органов местного самоуправления были тем шире, чем дальше от центра находилась подведомственная территория (Дамешек, 2012, с. 17). Процесс определения этнической «линии» в региональном управлении и степень ее жесткости также в значительной степени зависели от желания и способности самого этноса соответствовать предъявляемым ему условиям интегрирования в чужеродную среду. Появление этнических меньшинств в качестве «чужих» предполагало сложный процесс «удвоения» этнических качеств: усвоение нового языка, иной системы поведенческих стереотипов и доминирующих обычаев при сохранении, по крайней мере, в период адаптации, культурно-исторического потенциала своего этноса (Ишмуратов, 2003, c. 89).

Не претендуя на анализ региональных нюансов отношения власти к каждой из заметных этнических общностей, мы решили рассмотреть их на примере двух «связок»: поляки - евреи и евреи китайцы. При кажущейся парадоксальности выбора в контексте нашего исследования он имеет определенную логику.

\section{ПОЛЯКИ И ЕВРЕИ: ДВА ПОЛЮСА В РЕГИОНАЛЬНОЙ «ШКАЛЕ ТЕРПИМОСТИ»}

Первая связка определяется сходством позиций двух этносов в выстроенной А. Каппелером шкале интенсивности, с какой разные народы Российской империи подвергались унифицирующей интеграции, и большой разницей в отношении к ним со стороны региональной администрации, несмотря на одинаковый, вдвойне ущербный правовой статус - как ссыльных и как представителей «неблагонадежных» этносов. На общероссийском уровне поляки занимали верхнюю ступеньку шкалы из-за весьма сильных сепаратистских настроений в Польше, угрожающих целостности империи. С 1830-х гг., на протяжении, по крайней мере, четырех десятилетий поляки считались синонимом возмутителей общественного спокойствия и 
численно преобладали среди государственных преступников, определяя облик политической ссылки. Поэтому по отношению к ним применялась бескомпромиссная интеграция: насильственная унификация, репрессии против католического духовенства, открытая культурно-языковая русификация. Политика по отношению к евреям вообще выходила за рамки данной шкалы и часто лежала за пределами правового поля. Евреи прочувствовали на себе всю тяжесть политики дискриминации и сегрегации (Каппелер, 2000, сс. 206-207, 187-188). Однако «еврейская» политика империи была непоследовательной и отличалась метаниями между попытками включения дистанцировавшихся от общества евреев в российскую действительность и созданием барьеров на пути их интеграции в российский социум, когда прежняя политика начинала приносить плоды в виде стремительного роста процента ассимилированных, европейски образованных евреев. Неопределенность особенно рельефно проявилась в определении статуса евреев как «инородцев», хотя «Устав об управлении инородцев» 1822 г. на них не распространялся (Слокум, 2005, сс. 503, 513). По мнению исследователей, отнесение евреев, оседлых жителей европейской территории, к одной категории с народами «низкого культурного уровня» было их преднамеренным унижением - без предоставления положенных им в таком случае льгот: «инородческого» самоуправления и освобождения от рекрутской повинности (Klier, 1989, p. 132). Причин определения евреев в группу, в отношении которой следует применять жесткий прессинг, по крайней мере, три. Первая - их враждебность христианству и постоянные, хотя и ничем не обоснованные опасения еврейского прозелитизма. Православная церковь даже не пыталась вести среди евреев миссионерскую деятельность, за исключением разве что кантонистских батальонов, хотя усердствовала в обращении в православие других нерусских этносов. Вторая - необходимость защиты «слабого, едва нарождающегося русского капитализма от еврейской доминации» в условиях форсированной модернизации экономики (Миллер, 2012, с. 127). Наконец, подозрения евреев в их всеобщем увлечении революционной идеей, что в значительной степени соответствовало действительности: к концу 1880-х гг. евреи составили «критическую массу» в русском революционном движении (Haberer, 1995, pp. 256-257). В конце XIX в. поляки и евреи в русском общественном сознании составляли единую «темную» силу.

Политика по отношению к «европейским» этническим группам в Забайкалье кардинально отличалась от «инородческой». Это вполне 
объяснимо: поляков и евреев не было необходимости искусственно встраивать в новую систему производственных отношений, они легко вписались в нее сами. В отношении к обеим этническим группам областная администрация особенно рельефно продемонстрировала независимость своей позиции, самостоятельно определяя для них роль фаворитов или, соответственно, париев. В качестве привилегированного «сословия» она выделила поляков, что резко расходилось с позицией центральной власти, видевшей в них исключительно государственных преступников и изрядно опасавшейся из разрушительной «противоправительственной» деятельности в местах ссылки. Пренебрегая «польской» политикой центра, в соответствии с которой ссыльные поляки не имели права заниматься преподавательской деятельностью, содержать аптеки, типографии, фотографии, иметь медицинскую практику, служить в правительственных учреждениях и т.д., местная власть проявила удивительный прагматизм в успешном использовании их образовательного и духовного потенциала для решения региональных задач. (Здесь мы как раз наблюдаем зыбкую границу между «польской» политикой и отношением к полякам как сосланным преступникам). Забайкальская администрация в отношении к полякам следовала в общесибирском русле: они легко находили себе достойное применение - вплоть до занятия низших административных и выборных должностей (Шайдуров, 2013, сс. 181-182). Регион, испытывавший острую нехватку врачей, педагогов и других специалистов, охотно «замещал» их ссыльными поляками, уровень образования которых был заметно выше, чем у местного населения.

Незнание особенностей данной этнической группы (история, численность и социальная структура, обстоятельства вхождения в империю) приводило к ошибкам в процессе ее включения в экономическую жизнь региона. Чего только стоила крайне неудачная затея приобщить поляков к земледелию, которую сибирские власти предприняли после их массовой ссылки в результате подавления восстания 1863-1864 гг.! Непривычные к крестьянскому труду польские шляхтичи быстро проматывали казенное пособие, выданное на обзаведение хозяйством, и становились обузой для сибирских старожилов (Мулина, 2004, сс. 141-142). Уверенность забайкальской администрации в том, что в регионе пришлому человеку легко прокормиться торговлей или работой на золотых приисках, поляками тоже была изрядно поколеблена: для большинства из них она была лишь средством выживания в тяжелых условиях ссылки (Гапоненко \& Семенов, 2006, сc. 75-76). 
В отличие от региональной «польской» политики отношение к евреям в Сибири практически полностью копировало имперский курс на их всяческое ущемление, пожалуй, даже в более жестком варианте, предусматривающем массу запретов. Среди них - «запрет на профессии»: например, Правительствующий Сенат по делу Лейбович запретил евреям винную торговлю, хотя это было их традиционным занятием в черте оседлости. Запрет пребывания евреев в 100-верстной полосе от китайской границы вынудил выселиться отсюда даже тех, кто владел в «запретной зоне» золотыми приисками. Закон действовал и после отмены аналогичного запрета пребывания евреев в 50-верстной полосе от западной границы. Но особенно региональные власти переусердствовали в ограничении права евреев на передвижение. Их выход за черту еврейской оседлости в Сибири был «компенсирован» очертанием жизненного пространства рамками волости или уезда, покинуть которое они не имели права без специального разрешения. Это уникальное, не практиковавшееся по отношению ни к какому другому народу явление позволило нам ввести в научный оборот категорию «сибирская черта еврейской оседлости», которая расширялась/сужалась в зависимости от представлений региональных чиновников об опасности, которую евреи несут сибирскому обществу (Кальмина, 2003, сс. 49-60).

Исследователям сибирского еврейства еще предстоит найти объяснение такой исключительности. Стереотипы еврейской опасности, хорошо прижившиеся в европейской части империи и твердо усвоенные разработчиками законов, в Сибири не работали. Евреи не ломали сложившейся системы разделения труда, а удачно вписывались в нее, занимая свободные ниши и воспроизводя привычные, необходимые региону занятия, в первую очередь, торговое посредничество. Они не ущемляли прав других этносов и не ставили их на грань выживания успешной конкуренцией. Не составляли «критической массы» в населении региона: в Иркутской губернии, например, на 1897 г. их доля равнялась всего 1,46\%, в Забайкальской области - 1,1\% (Кальмина, 2003, с. 352). Не было никаких оснований подозревать их в «поголовном революционаризме»: Сибирь оказалась на периферии русского революционного движения. Да и свою раздражающую «обособленность», породившую многолетнюю целенаправленную имперскую политику интеграции евреев в российскую действительность, они здесь не демонстрировали. Напротив, проявили редкую способность при сохранении этнической идентичности выглядеть и думать как местное население, успешно копируя не только его пове- 
денческие стереотипы, но даже психологические установки (Рабинович, 2002, с. 117). Причиной региональной инициативы в ужесточении «еврейского» законодательства мы считаем актуальность и для Сибири стереотипа о «хищнической изворотливости» евреев, от которой надо было защитить беспомощного перед ней простодушного сибирского крестьянина. (Население европейской части России, по представлениям сибирских чиновников, к ней уже приспособилось). Недаром же «еврейское» законодательство всячески сдерживало въезд евреев в Сибирь, каждый раз изобретая предлоги для отказа в таковом. А ограничение свободы передвижения уже оказавшихся в регионе евреев было самым действенным инструментом по сдерживанию их активности, «несовместной с хозяйственным бытом поселян» (РГИА, 1852, лл. 4 б, 121). Не следует сбрасывать со счетов и государственный антисемитизм, бывший чуть ли не профессиональным маркером чиновничества всех рангов, в том числе и сибирского.

Однако «сибирская черта» не смогла остановить еврейскую напористость, тем более что основным «еврейским» занятием была торговля, требующая мобильности. Евреи постоянно нарушали правила своей «оседлости», достаточно свободно передвигаясь по региону и проживая вне мест своей приписки - фактически при попустительстве власти. Неопределенность в законоположениях, допускающая разнообразное, часто противоречивое, толкование плюс физическая неспособность региональной администрации контролировать их точное исполнение играли на руку евреям, которые могли игнорировать ограничения без последствий для себя. Однако, пожалуй, главной причиной снисходительного отношения сибирских губернаторов к еврейской «самодеятельности» была их признанная обществом польза, которую они приносили краю.

Сибирь как активно колонизуемый регион открывала невиданный простор для предприимчивых людей, что позволило евреям в короткое время стать весьма заметными в ее экономике. Носители капиталистического способа производства в регионе, они быстро заняли лидирующее положение во многих отраслях экономики, несмотря на ущемленный правовой статус. Но успехи в Забайкалье выглядят феноменом даже на фоне их роли в развитии Сибири в целом: здесь они составили деловую элиту области. В торговле пушниной, готовым платьем, металлическими изделиями, скобяными товарами, оконным стеклом они занимали лидирующие позиции. В купеческих гильдиях забайкальских городов их процент доходил 
до 70, хотя доля в городском населении не превышала $15 \%$, а в числе купцов первой гильдии евреи составляли абсолютное большинство. В каждом из городов, в том числе и административном центре области Чите, на рубеже XIX - XX вв. евреи владели более чем половиной торгово-промышленных фирм (Кальмина, 2003, сс. 141, 142, 394), хотя региональная власть, не желавшая наводнять города ссыльным элементом, старалась ограничить им доступ в городскую местность.

На наш взгляд, в этом значительную роль сыграла восточная геополитическая стратегия империи, предусматривавшая экономическое укрепление забайкальского региона как торгово-промышленного плацдарма на пути к завоеванию Внутренней Азии. С этим следовало поторопиться: даже на рубеже XIX-XX вв. Забайкалье оставалось «ахиллесовой пятой» сибирской экономики, сохранявшей сырьевую специализацию. Между тем сосланные сюда евреи, даже при их малочисленности, могли поспособствовать решению задачи, ибо были «талантливыми колонизаторами с исторически развившейся способностью быть носителями капиталистического духа» (Войтинский \& Горштейн, 1915, сс. 89, 235) и могли преподать населению Забайкалья, с большим опозданием входившим в новую экономическую систему, уроки капитализма. Региональная администрация, метавшаяся между необходимостью соблюдать «еврейское» законодательство и развивать область, которой предстояло играть первые роли в укреплении восточных рубежей империи, выбрала меньшее из зол: предпочло закрыть глаза на многочисленные нарушения евреями «черты оседлости» - уже сибирской. Сложилась парадоксальная ситуация: ограничения в передвижении евреев, причиной которых стала их излишняя предпринимательская активность, фактически этой же активностью были и сняты.

Отношение к полякам как католикам и евреям как иудеям не вписывалось в имперскую политику, касающуюся иноверцев: в Сибири подход к этим инославным группам был совсем иным, нежели в западных губерниях империи. Если суть общероссийской политики в отношении католицизма заключалась в разработке и принятии мер, снижающих его влияние до совершенно безопасного для империи уровня, вплоть до полного его упразднения (Сталюнас, 2005, с. 570), то в Сибири даже не практиковалось насильственное обращение в православную веру - только стимулирующее. Перешедшие в православие получали различные льготы. Второй региональной особенностью было отсутствие препятствий к открытию католических костелов. Нерчинский римско-католический приход был 
открыт сразу после ссылки в сюда участников восстания 1831 г. С появлением устойчивой польской этнической общности в уездном Верхнеудинске разрешение на открытие костела также было получено без затруднений (ГАРБ, 1907, л. 2). Евреев к переходу в православие тоже не принуждали. Но они меняли вероисповедание чаще других из чисто прагматических соображений: для получения права свободного передвижения или образования в обход установленной для них процентной квоты. Однако, хотя с переходом в православие права евреев существенно расширялись, в Забайкалье факты их крещения были единичны, видимо, в силу их и без того прочного положения в деловом сообществе. Препятствий к работе еврейских молитвенных домов, как правило, не чинилось. Но, если по каким-то причинам получить разрешение на их регистрацию не удавалось, самовольное открытие не влекло за собой никаких карательных мер, а по прошествии времени факт их существования признавался властью (Кальмина, 2003, сс. 249-254).

Таким образом, мы приходим к выводу: несмотря на то, что ссылка оставалась значительным источником формирования некоренных этнических сообществ в Забайкалье, этническая политика здесь проводилась в более мягком варианте, чем в западных территориях империи. Во-первых, в отличие от центральной власти, для которой наиболее важным было карательное значение ссылки, региональная власть рассматривала ее в первую очередь как способ заселения края и преодоления дефицита трудовых ресурсов, что было необходимым условием для его экономического освоения (Ремнев, 1994, с. 67). Как показало время, эти ожидания власти вполне оправдались. Нуждавшийся в быстрой капитализации Забайкальский регион, на который возлагались большие надежды в амбициозных планах империи, сумел в полной мере использовать высокий образовательный уровень и опыт деятельности в рыночных условиях новых забайкальцев в разных отраслях экономики, медицине, научных исследованиях. Во-вторых, некоренные этнические группы были малочисленны и, в силу своей отдаленности от основной массы единоверцев и многолетней жизни в «рассеянье», не представляли опасности для целостности империи. Религиозные сообщества, организационно оформившись сравнительно поздно, также не успели обрести серьезного влияния, и их прозелитизм региону не угрожал.

В начале XX в. Забайкалье как место будущих крупных инвестиций и пластичной политики региональной власти по отношению к этническим меньшинствам стало притягательным и для вольных 
переселенцев разной этнической принадлежности. С регионом связывались надежды заработать деньги, сделать карьеру и избежать крайностей в этнической политике государства, с которыми сталкивались их единоверцы в западных губерниях империи.

\section{ЕВРЕИ И КИТАЙЦЫ: РОДСТВО ПОВЕДЕНЧЕСКИХ СТРАТЕГИЙ}

Параллель, которую мы собираемся провести в данном фрагменте, на первый взгляд кажется абсолютно некорректной. Что, собственно, общего может быть между евреями и китайцами в сибирской провинции? Первые - подданные Российской империи, оказавшиеся в регионе большей частью не по своей воле, неполноправные, вечно «крайние», на которых списывались все российские беды от разорения соседней лавки из-за неумелого ведения дел до стремительного роста революционных настроений. Вторые - иностранцы, оказавшиеся в регионе добровольно, имеющие преференции в бизнесе, за спиной которых стояла могучая империя, «заклятый друг» России. Однако при столь впечатляющей разнице правового положения адаптационные стратегии евреев и китайцев, позволившие им утвердиться на забайкальском экономическом поле, оказались на удивление схожи (хотя всякое сравнение, как известно, хромает). А это, в свою очередь, потребовало от региональной власти разработки во многом общей для обоих этносов линии поведения.

Процент китайцев в российских пределах стал заметно повышаться в результате подписания в 1860 г. Пекинского договора, предоставившего подданным Поднебесной империи право торговли в России. Первоначально они оседали большей частью в Забайкалье, в населении которого быстро стали заметной, экономически активной группой - хотя, согласно Переписи 1897 г., они составляли всего 0,3\% населения области. Чуть раньше мы отмечали, что евреи в поисках сферы занятий в регионе никому не создали конкуренции, заняв свободную нишу в его экономической структуре - торговое посредничество. Китайцы пришли на занятое место, составив конкуренцию именно евреям. Во-первых, родом своих занятий: точно так же первым и основным их видом в Забайкалье стала торговля. Во-вторых, местами приложения предпринимательских талантов, которыми тоже стали забайкальские города, и всепроникающей способностью: в области не было сколько-нибудь значительного населенного пункта, где бы не открылся китайский магазинчик - часто рядом с еврейским. Так же как у евреев, процент китайцев среди торгующих был значи- 
тельно выше их доли в городском населении (ГАРБ, 1881, лл. 1-144; 1908 , л. 63) В-третьих, мобильностью и хорошим знанием конъюнктуры, что ранее составляло исключительную особенность еврейской торговли. Тех и других всегда можно было встретить в местах наибольшего скопления потребителей. Появившиеся на знаменитой Верхнеудинской ярмарке китайцы, так же как и еврейские торговцы, не выдержав на ней конкуренции крупных торговых фирм, без труда реализовывали нераспроданные товары в уезде среди крестьян, по каким-то причинам на ярмарку не приехавшим. Наконец, они были похожи торговым «поведением»: охотно давали товары в долг для обретения постоянного покупателя; не гонялись за быстрым барышом, работая на перспективу; делали ставку не на высокую цену товара, а на быструю оборачиваемость денег.

Однако при всем сходстве у китайского предпринимательства была серьезная фора. Оно было защищено международным правом, создавшим для него льготные условия: в октябре 1861 г. была разрешена свободная беспошлинная торговля китайцев в Забайкалье (Шахеров, 2011, с. 173). А правилами 20 февраля 1862 г. закреплялось право беспошлинной торговли в 50-верстной полосе на всем протяжении китайской границы. Предоставленные льготы позволяли китайцам держать демпинговые цены и быть вне конкуренции, что вызвало законное недовольство торговцев Забайкалья, поставленных в заведомо невыгодные условия. А если вспомнить закон о запрещении евреям находиться в 100-верстной приграничной полосе, то получается, что государство здесь своими руками устранило главных конкурентов китайских торговцев. «Весовые категории» оказались неравными. В то время как евреи вынуждены были выселиться отсюда, оставив даже принадлежащие им золотые прииски, китайцы, не удовлетворившись легальной торговлей, промышляли контрабандой, ввозя в больших объемах товары, которые потом продавали в своих лавках.

Бесконтрольная и беспошлинная китайская торговля стала настоящим бедствием для Забайкалья. Противозаконная торговая тактика требовала «симметричного» ответа для защиты прав местных предпринимателей. Борьба за распространение на торгующих в России китайцев положенных пошлин затянулась почти на 20 лет (Башкуева, 2009, с. 207), после чего их льготы были ограничены, и они могли вести беспошлинную торговлю только в 50-верстной приграничной полосе. Но это ничего не изменило: китайцы продолжали торговать без документов, а при попытках российской стороны выну- 
дить к их соблюдению новых правил жаловались в Министерство иностранных дел в Пекине (ГАРБ, 1876-1880, лл. 19, 60; Башкуева, 2009, c. 212).

Возмущенный нежеланием китайцев платить пошлину, забайкальский военный губернатор И. К. Педашенко при поддержке председательствующего в Совете Главного управления Восточной Сибири К.Н. Шелашникова настаивал на закрытии китайской торговли и депортации упорствующих нарушителей. Но российский посланник в Китае А. Кояндер, опасаясь осложнений в российскокитайских отношениях, был категорическим противником столь радикальных мер и настаивал на мирном урегулировании щекотливого вопроса. С его подачи Забайкальское областное правление приняло решение открыть опечатанные лавки нарушителей и вернуть им деньги, взысканные в качестве штраффа (ГАРБ, 1876-1880, лл. 68, 96, 98). Зная тонкости восточного менталитета, принимающего любую уступку за слабость, забайкальские городские власти считали такое решение большой ошибкой: это фактически разрешало китайцам продолжать беспатентную торговлю. С другой стороны, от опечатывания китайских лавок и угроз штрафов толку было мало: китайцы просто снимали вывески и продолжали торговлю.

В своем нежелании соблюдать правила, создающие препятствия их торговле, китайцы были очень похожи на евреев, тоже не очень-то следующих запретам свободного передвижения. Однако и здесь правовое преимущество китайцев было очевидным. При нарушении закона евреи, как минимум, рисковали быть выселенными к месту приписки и реквизицией собственности, которой в запрещенном месте нахождения успели обзавестись. Китайцы не рисковали ничем. Напротив, опасения ответных действий китайской стороны по отношению к русскому купечеству делали их неуязвимыми даже при полном пренебрежении законодательством. Но, несмотря на диаметрально противоположную разницу правового статуса, евреи не спасовали перед конкурентом. Обе этнические группы были одинаково успешны в торговом бизнесе. Это можно объяснить широтой торгового пространства Забайкалья: на его огромной, слабо населенной территории с неразвитой транспортной инфраструктурой и острой нуждой в развитии любой отрасли экономики каждый при желании мог найти сферу приложения усилий. Определенную роль сыграла и торговая специализация обеих этнических групп, позволившая каждой из них иметь своего покупателя. Евреи торговали предметами первой необходимости, не гоняясь за престижностью и часто оказывая 
услуги в реализации дешевых товаров. У китайцев, напротив, специализация была выражена четко: чай, сахар, ткани, прочие «китайские товары».

Из-за сходства поведенческих стратегий китайцев и евреев и их уверенном положении в главной отрасли региональной экономики забайкальское общество воспринимало их как единого конкурента, соперничество с которым при равных условиях было делом бесполезным. Значительную сумму недоимок, лежащих на мещанском обществе к 1 января 1877 г., в числе прочих причин Верхнеудинская городская управа объяснила «прогрессивным наплывом в город Верхнеудинск евреев и китайцев, захвативших в свои руки мелочную торговлю» и «лишающих горожан необходимых заработков для платежа повинностей» (ГАРБ, n.d., л. 13-14). Поэтому в политике по отношению к ним просматривалась общая линия: защита русского бизнеса от их излишней предприимчивости, постоянно балансирующей на грани нарушения закона.

\section{ЗАКЛЮЧЕНИЕ}

Хотя имперская этническая политика экстраполировалась на все регионы Российской империи, при сложном административном устройстве государства с территориями, существенно отличавшимися по уровню социально-экономического развития и этнической структуре, эта политика в значительной степени варьировалась. Сибирь как окраинный регион империи также не была однородной: Забайкальская область занимала в ней особое место, обусловленное геополитической ролью «ворот в азиатское пространство», которой она мало соответствовала из-за значительной доли штрафоной колонизации в населении и низкого, даже по сравнению с остальной Сибирью, уровня экономического развития. Это положение диктовало особенности процесса конструирования полиэтничного сообщества и относительную независимость региональной администрации в проведении этнической политики. По отношению к коренному этносу эта политика прошла путь от сохранения традиционных структур управления и опоры на местную элиту до приобретения ярко выраженного колонизаторского характера, проявившегося в русификации коренного населения, унификации органов самоуправления, перевода инородцев к оседлому образу жизни и привлечению к православию. Ее стержнем в отношении некоренных этнических групп стало значительное смягчение по сравнению с таковой в западных регионах империи, хотя главной составляющей переселенцев в регионе была штрафная коло- 
низация. Для региональной власти они в первую очередь были важным колонизационным элементом, призванным способствовать капитализации области. Разница в отношении к той или иной этнической группе диктовалась многими факторами: от конъюнктурной политической ситуации и взаимоотношений с регионом компактного проживания того или иного этноса (на территории империи или за ее пределами) до собственных представлений областной администрации о степени его полезности колонизуемому региону. Деловой потенциал переселенцев из европейской России, уже вовлеченных в систему капиталистических отношений, а в ряде случаев являвшихся их носителями, был востребован и оценен региональной администрацией и местным обществом. Поэтому инкорпорация некоренных этнических групп в сибирский социум была относительно легкой и вполне успешной.

\section{БЛАГОДАРНОСТИ}

Статья подготовлена в рамках государственного задания, проект «Россия и Внутренняя Азия: динамика геополитического, социальноэкономического и межкультурного взаимодействия (XVII -XXI вв.)», № $121031000243-5$.

\section{Список литературы}

Haberer, E. (1995). Jews and Revolution in Nineteenth-Century Russia. Cambridge: Cambridge University Press.

Klier, J. (1989). The Concept of «Jewish Emancipation» in a Russian Context. In O. Crisp \& L. Edmundson (Eds.), Civil Rights in Imperial Russia (pp. 121-144).

Oxford: Clarendon press.

Андреев, Ч. Г. (2013). Политика царского правительства и степень проникновения мировых религий в среду коренных народов Восточной Сибири во второй половине XIX - начале XX в. В Сибирь в империи - империя в Сибири: Имперские прочессы на окраинах России в XVII - начале XX в (сс. 153-166).

Иркутск: Оттиск.

Башкуева, Е. Ю. (2009). Правовой статус китайских торговцев в Забайкальской области (вторая половина XIX в.). В Третьи университетские социальногуманитарные чтения 2009 года: Материаль. Том 2 (сс. 206-214). Иркутск: Издательство Иркутского государственного университета.

Войтинский, В., \& Горштейн, А. (1915). Евреи в Иркутске. Иркутск: Издание Хозяйственного Правления Иркутского Еврейского Молитвенного Дома и Иркут- 
ского Отдела Общества Распространения Просвещения между евреями России.

Гапоненко, В. В., \& Семенов, Е. В. (2006). Польские политические ссыльные в хозяйственной и культурной жизни Забайкалья в первой половине XIX века. Улан-Удэ: Издательско-полиграфический комплекс ФГОУ ВПО ВСГАКИ.

Горизонтов, Л. Е. (2004). Польский вопрос в кругу «роковых вопросов» Российской империи (1831 год - начало XX века). В Государственное и муниципальное управление в России. История и современность (сс. 65-80). Самара: Издательство Самарского муниципального института управления.

Государственный архив Республики Бурятия. $(1876,1880)$. Ф.10. On.1. Д.112.

Государственный архив Республики Бурятия. (1881). Ф.10. Оn.1. Д.325.

Государственный архив Республики Бурятия. (1907). Ф.10. Оп.1. Д. 1877.

Государственный архив Республики Бурятия. (1908). Ф.10. Оп.1. Д.2720.

Государственный архив Республики Бурятия. (б. д.). Ф.10. Оп.1. Д.220.

Дамешек, И. Л. (2005). Российские окраины в имперской стратегии власти (начало XIX - начало XX вв.). Иркутск: ИГПУ.

Дамешек, И. Л. (2013). Типологическая характеристика и региональные особенности российских окраин XIX в. В Сибирь в империи - империя в Сибири: имперские прочессы на окраинах России в XVII - начале XX в. (сс. 216-230).

Иркутск: Оттиск.

Дамешек, Л. М. (2012). Сибирь в империи: империя в Сибири. Значение этнического фактора в окраинной политике Российской империи. Этапы становления и направления. Известия Иркутского государственного университета. Серия: История, (2-1), 13-19.

Дамешек, Л. М. (2018). Сибирские «инородцы» в имперской стратегии власти (XVIII - начало XX в.). Иркутск: Оттиск.

Жалсанова, Б. Ц. (2013). Подготовительная работа по проведению волостной реформы у бурят Забайкальской области (1897-1904 гг.). В Сибирь в империи империя в Сибири: имперские прочессы на окраинах России в XVII - начале $X X$ в. (сс. 167-176). Иркутск: Оттиск.

Иванов, А. А., Кальмина, Л. В., \& Курас, Л. В. (2012). Забайкальская периферия на переломе эпох (1880-1920-е г2). Иркутск: Оттиск.

Ишмуратов, Б. М. (2003). Сибирь в российской и мировой перспективе. Иркутск: Оттиск.

Кальмина, Л. В. (2003). Еврейские общины Восточной Сибири (середина ХІХ в. - Февраль 1917 года). Улан-Удэ: Издательско-полиграфический комплекс ВСГАКИ.

Кальмина, Л. В. (2006). Закон 12 июня 1860 года как результат провала сибирской «еврейской» законодательной политики 1837 года. В Материалы Тринадцатой Ежегодной Международной Междисциплинарной конференции по иудаике. Академическая серия. Bып. 20 (сс. 393-399). Москва. 
Кальмина, Л. В. (2020). «Еврейская» политика сибирских губернаторов: отклонение от «генеральной линии». Вестник Томского государственного университета. История, (64), 12-17. doi: 10.17223/19988613/64/2

Кальмина, Л. В., \& Малыгина, О. А. (2016). «Блюститель неприкосновенности»: институт военного губернатора Забайкальской области. Улан-Удэ: Издательство Бурятского госуниверситета.

Каппелер, А. (2000). Россия-многонациональная империя. Возникновение. История. Распад. Москва: Прогресс-Традиция.

Мерцалов, В. И. (2008). Геополитический фактор исторического развития Забайкалья и Читы (1841-1895). Научный вестник Байкальского государственного университета экономики и права, (3), 26-33.

Миллер, А. И. (2012). Этноконфессиональный фактор в развитии Российской империи (конец XVIII - начало XX в.). В Т. Ю. Красовицкая \& В. А. Тишков (Ред.), Этнический и религиозный фактор в формировании и эволюиии российского государства (сс. 102-150). Москва: Новый хронограф.

Мулина, С. А. (2004). Ссыльные участники восстания 1863 г. в западносибирской деревне. В Сибирская деревня: история, современное состояние, перспективы развития. Bып. 1 (сс. 141-144). Омск: Издательство Омского государственного аграрного университета.

Рабинович, В. Ю. (2002). Евреи дореволюционного Иркутска: меняющееся меньшинство в меняющемся обществе. Красноярск: Издательство «Кларетианум».

Ремнев, А. В. (1994). Самодержавие и Сибирь в конце XIX - начале XX века: проблемы регионального управления. Отечественная история, (2), 60-73.

Российский государственный исторический архив. (1852). Ф. 383. On.15. Д. 18271.

Сандерланд, В. (2005). Русские превращаются в якутов? «Обынородчивание» и проблемы русской национальной идентичности на Севере Сибири, 1870-1914. В Российская империя в зарубежной историограбии. Работы последних лет (сс. 199-227). Москва: Новое издательство.

Слокум, Дж. У. (2005). Кто и когда были «инородцами»? Эволюция категории «чужие» в Российской империи. В Российская империя в зарубежной историографии. Работы последних лет (сс. 199-227). Москва: Новое издательство.

Тишков, В. А. (2005). Этнология и политика: статьи 1989-2004 гг. Москва: Наука.

Тишков, В. А. (2013). Российский народ: история и смысл нащионального самосознания. Москва: Наука.

Шайдуров, В. Н. (2013). Евреи, немцы, поляки Западной Сибири XIX - начала XX в. Санкт-Петербург: Издательство Невского института языка и культуры.

Шахеров, В. П. (2011). Экономика сибирского дореформенного города (на материалах городов Байкальской Сибири). Иркутск: Издательство Иркутского государственного университета. 
Шостакович, Б. С. (2008). Насущные задачи координации полонийной научноисследовательской и издательской работы в Восточносибирском регионе. В Современные тенденции развития полонийного движения в России: материалы междунар. научн.-практ. конф., г. Улан-Удэ, 19 сент. 2008 (сс. 182-189). Улан-Удэ: ВСГАКИ.

\section{References}

Andreev, Ch. G. (2013). The policy of the tsarist government and the degree of penetration of world religions among the indigenous peoples of Eastern Siberia in the second half of the 19th and early 20th centuries. In Siberia in the Empire - Empire in Siberia: Imperial Processes on the Outskirts of Russia in the Seventeenth and Early Twentieth Centuries (pp. 153-166). Irkutsk: Imprint. (In Russian).

Bashkueva, E. Yu. (2009). Legal status of Chinese merchants in Transbaikalia Province (second half of the 19th century). In Third University Social-Humanitarian Readings 2009: Proceedings. Vol. 2 (pp. 206-214). Irkutsk: Irkutsk State University Press. (In Russian).

Dameshek, I. L. (2005). Russian Outskirts in the Imperial Strategy of Power (early nineteenth to early twentieth centuries). Irkutsk: IGPU.. (In Russian).

Dameshek, I. L. (2012). Siberia in the Empire: The Empire in Siberia. The significance of the ethnic factor in the marginal policy of the Russian Empire. Stages of formation and directions. Izvestia of the Irkutsk State University. Series: History, (2-1), 13-19. (In Russian).

Dameshek, I. L. (2013). Typological characteristics and regional peculiarities of the Russian outskirts of the 19th century. In Siberia in the Empire - Empire in Siberia: Imperial Processes on the Margins of Russia in the Seventeenth and Early Twentieth Centuries. (pp. 216-230). Irkutsk: Imprint. (In Russian).

Dameshek, I. L. (2018). Siberian "foreigners" in the imperial strategy of power (18th - beginning of the 20th century). Irkutsk: Imprint. (In Russian).

Gaponenko, V. V., \& Semenov, E. V. (2006). Polish political exiles in the economic and cultural life of Transbaikalia in the first half of the 19th century. Ulan-Ude: Publishing-Polygraphic Complex of the Federal State Educational Institution of Higher Professional Education VSGAKI. (In Russian).

Gorizontov, L. E. (2004). The Polish Question in the Circle of "Fatal Questions" of the Russian Empire (1831 - the Beginning of the 20th Century). In State and Municipal Governance in Russia. History and Modernity (pp. 65-80). Samara: Publishing house of the Samara Municipal Institute of Management. (In Russian).

Haberer, E. (1995). Jews and Revolution in Nineteenth-Century Russia. Cambridge: Cambridge University Press.

Ishmuratov, B. M. (2003). Siberia in Russian and World Perspective. Irkutsk: Imprint. (In Russian). 
Ivanov, A. A., Kalmina, L. V., \& Kuras, L. V. (2012). The Transbaikal Periphery at the Turn of Epochs (1880s-1920s). Irkutsk: Imprint. (In Russian).

Kalmina, L. V. (2003). Jewish Communities of Eastern Siberia (mid-nineteenth century February 1917). Ulan-Ude: VSGAKI Publishing and Printing Complex. (In Russian).

Kalmina, L. V. (2006). Law of June 12, 1860 as a result of the failure of the Siberian "Jewish" legislative policy of 1837. In Proceedings of the Thirteenth Annual International Interdisciplinary Conference on Jewish Studies. Academic Series. Issue 20 (pp. 393-399). Moscow. (In Russian).

Kalmina, L. V. (2020). Siberian general-governor's Jewish policy: general trend deviation. Bulletin of Tomsk State University. History, (64), 12-17. doi: 10.17223/19 988613/64/2 (In Russian).

Kalmina, L. V., \& Malygina, O. A. (2016). "The Guardian of Inviolability”: The institution of the military governor of the Trans-Baikal region. Ulan-Ude: Buryat State University Press. (In Russian).

Kappeler, A. (2000). Russia-Multinational Empire: Origin. History. Disintegration. Moscow: Progress-Tradition. (In Russian).

Klier, J. (1989). The Concept of «Jewish Emancipation» in a Russian Context. In O. Crisp \& L. Edmundson (Eds.), Civil Rights in Imperial Russia (pp. 121-144). Oxford: Clarendon press.

Mertsalov, V. I. (2008). Geopolitical factor in the historical development of Transbaikalia and Chita (1841-1895). Scientific Bulletin of Baikal State University of Economics and Law, (3), 26-33. (In Russian).

Miller, A. I. (2012). The Ethno-confessional Factor in the Development of the Russian Empire (late 18 th - early 20 th centuries). In T. Yu. Krasovitskaya \& V. A. Tishkov (Eds.), The Ethnic and Religious Factor in the Formation and Evolution of the Russian State (pp. 102-150). Moscow: New Chronograph. (In Russian).

Mulina, S. A. (2004). The exiled participants of the 1863 uprising in a West Siberian village. In Siberian Village: History, Modern State, Prospects for Development. Issue 1 (pp. 141-144). Omsk: Publishing house of the Omsk State Agrarian University. (In Russian).

Rabinovich, V. Y. (2002). Jews of pre-revolutionary Irkutsk: A Changing Minority in a Changing Society. Krasnoyarsk: Claretianum Publishing House. (In Russian).

Remnev, A. V. (1994). The Autocracy and Siberia in the Late 19th and Early 20th Century: Problems of Regional Governance. National history, (2), 60-73. (In Russian).

Russian State Historical Archive. (1852). F. 383. In.15. C. 18271. (In Russian).

Shaidurov, V. N. (2013). Jews, Germans, and Poles in Western Siberia in the 19th and early $20^{\text {th }}$ centuries. St. Petersburg: Publishing house of the Nevsky Institute of Language and Culture. (In Russian).

Shakherov, V. P. (2011). Economics of a pre-reform Siberian city (on the materials of the cities of Baikal Siberia). Irkutsk: Irkutsk State University Press. (In Russian). 
Shostakovich, B. S. (2008). Current problems of coordination of polonium research and publishing work in the East Siberian region. In Current Trends in the Development of Polonium Movement in Russia: Proceedings of the International Scientific-Practical Conference "Polonium in Russia". Conf. Conf., Ulan-Ude, September 19, 2008. 2008 (pp. 182-189). Ulan-Ude: VSGAKI. (In Russian).

Slocum, J. W. (2005). Who and when were "non-Russians"? Evolution of the category of "aliens" in the Russian Empire. In The Russian Empire in Foreign Historiography. Works of recent years (pp. 199-227). Moscow: New Publishing House. (In Russian).

State Archives of the Republic of Buryatia. $(1876,1880)$. Ф.10. On.1. Д.112. (In Russian).

State Archives of the Republic of Buryatia. (1881). F.10. In.1. C.325. (In Russian).

State Archives of the Republic of Buryatia. (1907). F.10. In.1. C. 1877. (In Russian).

State Archives of the Republic of Buryatia. (1908). F.10. In.1. C.2720. (In Russian).

State Archives of the Republic of Buryatia. (б. д.). F.10. In.1. C.220. (In Russian).

Sunderland, W. (2005). Are Russians turning into Yakuts? "Obynorodchivanie" and Problems of Russian National Identity in Northern Siberia, 1870-1914. In The Russian Empire in Foreign Historiography. Works of recent years (pp. 199-227).

Moscow: New Publishing House. (In Russian).

Tishkov, V. A. (2005). Ethnology and Politics: Articles 1989-2004. Moscow: Nauka. (In Russian).

Tishkov, V. A. (2013). The Russian People. History and meaning of national self-consciousness. Moscow: Nauka. (In Russian).

Voytinsky, V., \& Gorshtein, A. (1915). Jews in Irkutsk. Irkutsk: Publication of the Economic Board of the Irkutsk Jewish Prayer House and the Irkutsk Department for Spreading Education among the Jews of Russia. (In Russian).

Zhalsanova, B. Ts. (2013). Preparatory Work for the Volost Reform in the Buryats of the Trans-Baikal Region (1897-1904). B Siberia in the Empire - Empire in Siberia: Imperial Processes in the Marchers of Russia in the Seventeenth and Early Twentieth Centuries. (pp. 167-176). Irkutsk: Imprint. (In Russian). 